\title{
SUCCESSFUL KIDNEY TRANSPLANTATION IN A PATIENT WITH MULTIPLE PERIOPERATIVE RENAL TRANSPLANT COMPLICATIONS. CASE REPORT
}

\section{Margarita Peneva ${ }^{1}$, Elizabeta Zjogovska ${ }^{1}$, Sasho Dohchev ${ }^{2}$, Sotir Stavridis ${ }^{2}$, Aleksandar Josifov ${ }^{3}$, Marija Jovanovski Srceva ${ }^{4}$, Anton Damevski ${ }^{4}$, Josif Janchulev ${ }^{2}$, Jelka Masin Spasovska ${ }^{5}$, Goce Spasovski ${ }^{5}$}

\author{
${ }^{1}$ University Clinic for Plastic and Reconstructive Surgery, Skopje, R. Macedonia \\ ${ }^{2}$ University Clinic of Urology, Skopje, R. Macedonia \\ ${ }^{3}$ University Clinic for Toracovascular Surgery, Skopje, R. Macedonia \\ ${ }^{4}$ Intensive Care Unit, Skopje, R. Macedonia \\ ${ }^{5}$ Department of Nephrology, Medical Faculty, University of Skopje, R. Macedonia
}

Corresponding Author: Margarita Peneva, University Clinic for Plastic and Reconstructive Surgery, Skopje, R. Macedonia; e-mail:mapeneva@yahoo.com

\begin{abstract}
Kidney transplantations have become common surgical procedures that are associated with high success rates. Nevertheless, the detection, accurate diagnosis and timely management of the perioperative surgical complications sometimes require multidisciplinary team approach for some of the complications may result in significant morbidity, risk of graft loss and/or mortality of the recipient. A case of a 24-year old male patient that developed a number of different surgical complications is reported. The complications included venous graft thrombosis, urinary fistula, wound infection, wound dehiscence and a completely exteriorized transplanted kidney. Despite the various complications and, accordingly, a couple of revisions, finally the patient was discharged with a regular kidney function.
\end{abstract}

Key words: kidney transplantation, surgical complications, wound dehiscence, plastic surgery

\section{Introduction}

A successful kidney transplant offers enhanced quality and duration of life and is more effective regarding the medical outcome, patient satisfaction and cost-effectiveness than long-term dialysis treatment in patients with end stage chronic kidney disease (CKD) [1]. The first kidney transplantation in the Republic of Macedonia was performed in 1977 and since then more than 360 adult and around 10 pediatric kidney transplantations have been performed [2, 3]. In the last years there were major political, legislative, medical and educational initiatives adopted to improve the kidney transplant program as a routine procedure in our country [4].

\section{Case report}

The aim of this paper is to report a case of a 24-year old male patient with end stage renal disease due to a minimal change glomerulonephritis. He has been treated many times by pulses of methylprednisolone and maintenance corticosteroid therapy and was presented with constitution small for date (BMI of 18.3).

All pre-transplant investigations have been performed and after a couple of months on dialysis he had been transplanted a kidney from his father as a living donor. Although there was a slightly mismatched proportion between the donated kidney and the recipient's constitution, the graft was transplanted on the left-side performing end to end internal iliac artery anastomosis and end to side external iliac vein ana- 
stomosis in the presence of short vein length. The uretero-vesical anastomosis was created according to the standard Lich-Gregoire procedure.

During the postoperative course the patient developed several complications. On the first day the postoperative diuresis was around $2000 \mathrm{ml}$. The ultrasound investigation showed daily worsening of the graft edema with a Doppler ultrasonography signal suggesting insufficient renal vein outflow. The renal CT angiography confirmed partial external iliac vein thrombosis. The thrombosis was due to the use of the left femoral vein for the dialysis catheter before transplantation. Venous thrombectomy was performed and an intensive course of anticoagulant therapy was administered. After a couple of days with an improved graft function a gradual increase in the proteinuria from 1.3 to 13.3 grams per day and diuresis reduction was noted. The ultrasonography examination showed again an edematous kidney with satisfying arterial perfusion. The transplant biopsy was contraindicated because of the enormous bleeding potential and this condition was considered as an acute rejection and/or recurrence of the baseline disease. A 3-day course of methylprednisolone $10 \mathrm{mg}$ per body weight was administered and 3 plasmapheresis procedures were performed. Despite the slow improvement in the graft function and reduction of the proteinuria, the parenchymal edema (23-26 mm) persisted. At the $13^{\text {th }}$ postoperative day a bleeding was noted around the transplanted kidney that required surgical revision. A small graft rupture near the renal hilum was detected. It was due to the external iliac vein stenosis that created a new thrombosis. Another venous thrombectomy associated with venoplasty was performed and the graft was enveloped in a vicryl mesh bag. In the following days the renal function completely recovered in the presence of insignificant proteinuria $<0.5 \mathrm{~g} /$ day.

One week later the patient had decreased diuresis again with a progressive and permanent graft pain. This time the CT scan confirmed ureteral necrosis with urinary fistula. The patient was operated and an anastomosis of the ureter of the graft with the contralateral native ureter of the recipient was performed.

Noteworthy, from the very beginning there was a mismatch between the proportions of the transplanted kidney and the size of the recipeent, thus making the soft tissue cover over the transplanted kidney insufficient. Namely, after the transplantation the skin was sutured under tension and was the only soft tissue coverage over the transplanted kidney. The skin was additionally damaged with every subsequent operation. Under such circumstances secondary soft tissue infection was highly expected. The microbiological examinations of the surgical wound at different time points revealed presence of various microorganisms including even Methicillin-resistant Staphylococcus aureus (MRSA) and Candida albicans which were successfully treated according to the antibiogram. The soft tissue infection additionally damaged the soft tissue cover $[5,6]$. Hence, after the last surgery the transplanted kidney was functioning well but it was completely exposed with a soft tissue defect over it sizing about $20 \times 10 \mathrm{~cm}$. Then, plastic surgeons were included as part of the surgical team.

Because of the several operations, the local anatomical structures were severely displaced and dense adhesions were present, thus making the dissection very difficult and risky. In addition, the patient was having serious comorbiddities (malnutrition, hypertension, immunocompromised condition) and had a long history of CKD with a couple of months on dialysis. More over at that time point he was getting depressed because of the long time spent in hospital along with the plenty of procedures he underwent. That was the rationale why it was decided to cover the soft tissue defect in the simplest way.

After the necrotic tissue was debrided the overall soft tissue defect became larger $(23 \times$ $12 \mathrm{~cm}$ ). A very long random skin flap from the upper third of the anterior abdomen was used in order to cover the defect (Figure 1). The flap was prepared as a transpositional one with the length to width ratio being $4,5: 1$. Starting at the first postoperative day there were signs of vascular insufficiency of the distal third of the flap that in the next days progressed to a complete necrosis (Figure 2). This problem was due to both the long flap and the infected recipient bed. At the $5^{\text {th }}$ postoperative day a necrectomy was performed when the distal third of the flap was removed. Then the tensor fasciae latae (TFL) fasciomyocutaneous flap was used as a pedicled flap in order to cover the reminder of the defect. As this flap is considered a thicker and a more vascularized one it was a way to deal with the soft tissue infection [7-9]. Namely, myofasciocutaneous flaps are golden standard for management of complicated infected wound bed. 


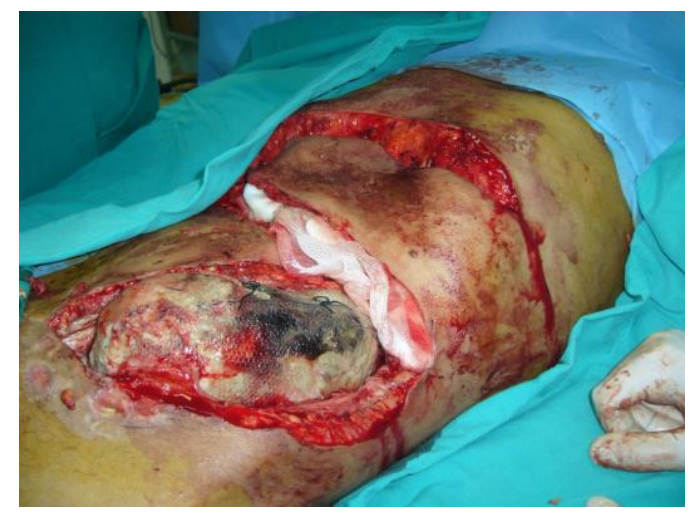

Figure 1 - Intraoperative view- completely exposed transplanted kidney after the necrotic tissue being debrided and the elevation of the abdominal random skin flap

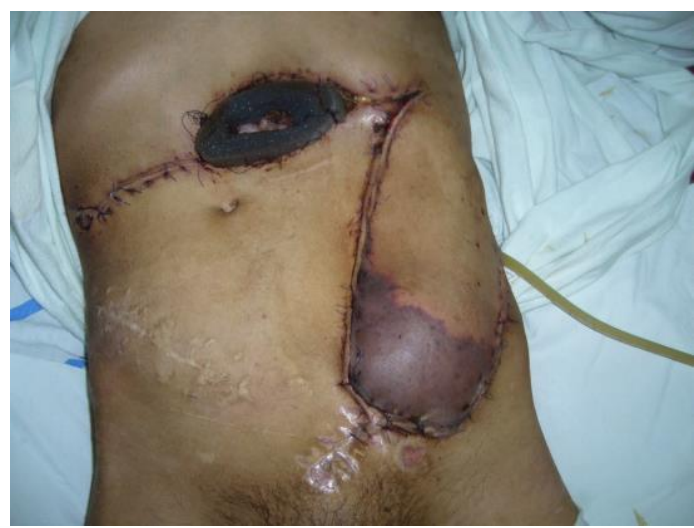

Figure 2 - Soft tissue necrosis of the distal part of the flap

Six weeks after the operation the flap was divided with a satisfying intraoperative result (Figure 3). Yet, two days later signs of vascular insufficiency on the distal part of the flap were noticed. Fortunately, this episode resolved only with partial dehiscence of the flap that healed spontaneously upon repeated dressings.

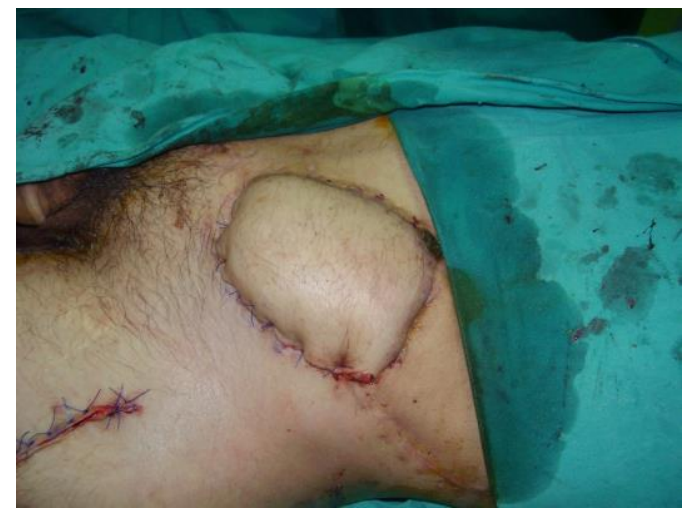

Figure 3 - Intraoperative view after the division of the TFL flap

The defect was successfully closed combining 2 different flaps at the same time avo- iding the microsurgical anastomosis. As a result the graft was saved and the anterior abdominal wall restored in the manner of function and esthetics. Even now, three years after the transplantation the results remained (Figure 4).

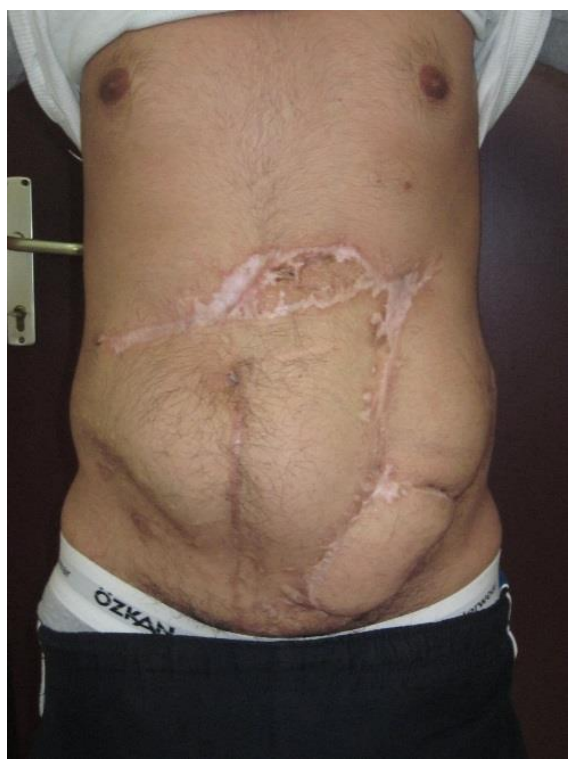

Figure 4 - Three years postoperative view of the flaps setting well over the defect

\section{Discussion}

Kidney transplantations have become common surgical procedures that are associated with high success rates. The complications associated with the procedure are low especially compared with other solid organ transplants. Nevertheless the detection, accurate diagnosis and timely management of surgical complications after kidney transplant are important tasks of the team managing these patients as some of the complications can result in significant morbidity of the recipient, risk of graft loss and mortality [10].

A case that developed a number of different surgical complications including venous thrombosis, wound infection, wound dehiscence and urinary fistula was presented.

Vascular complications despite being rare have devastating consequences particularly arterial and venous thrombosis [10]. Renal vein thrombosis (RVT) is usually seen during the first post transplantation week in $0.3-6.1 \%$ of patients. The prognosis of RVT is poor, and hence, its early recognition and treatment is crucial [11].

Approximately two thirds of the early urologic complications (urine leak or obstruction) occur in the first month after transplantation and are usually successfully treated by 
the transplantation team. However, the urological complication rates are $4-8 \%$ with a very low patient mortality [12].

Surgical site infections have remained major complications in solid organ transplanttation [5, 6]. Even worse, in this case there was a surgical site infection along with a completely exteriorized allograft. The allograft was prone to mechanical injury and to infection both of which could have almost inevitably lead to its loss. Covering the wound with well vascularized tissue can facilitate wound healing, resist the soft tissue infection and preserve the graft in general [8]. The reconstructive options for extensive lower trunk defects include both free flaps and pedicled flaps each having its own advantages and disadvantages [7]. Using a free flap would have been very difficult because of the very bad local conditions in the presence of soft tissue infection and other patients' comorbidities.

In conclusion, kidney transplant may be associated with various nephrological and surgical complications whose treatment require a multidisciplinary team work. Although at one time point the kidney was supposed to be unsalvageable, the great effort and persistent care invested from all the multidisciplinary team physicians, nurses and with the support from the psychologist and patient's family all complications were successfully over-passed and after a 4 month hospitalization the patient was discharged with a good graft function.

\section{REFERENCES}

1. Kaufman, D.B. (2015): Assessment and management of the renal transplant patient. Retrieved Nov06, 2015, from:

http://emedicine.medscape.com/article/429314overview.

2._Spasovski, G., Dohcev, S., \& Stankov, O. The improvement in kidney transplant program in R. Macedonia - what are the clues? 2013. Prilozi, 34: 9.

3. Spasovski, G., Mojsova-Miovska, M., \& Masin-Spasovska, J. The success of South-eastern Europe Health Network (SEEHN) initiative on improvement of the kidney transplant program-facts about Macedonia. Transpl Int. 2014; 27(7): e63-4.

4. Spasovski, G., Busic, M., \& Delmonico, F.(in press). The improvement in kidney transplantation in the Balkans after Istanbul Declaration - where do we stand today? Clin Kidney J.

5. Mehrabi, A., Fonouni, H., Wente, M., Sadeghi, M., Eisenbach, C., et al. Wound complications following kidney and liver transplantation. Clin Transplant. 2006; 20(17): 97-110.
6. Santangelo, M., Clemente, M., Spiezia, S., Grassia, S., Di Capua, F., et al. Wound complications after kidney transplantation in nondiabetic patients. Transplant Proc. 2009; 41(4): 1221-1223.

7. Rifaat, M.A. \& Abdel Gawad, W.S. The use of tensor fascia latapedicled flap in reconstructing full thickness abdominal wall defects and groin defects following tumor ablation. J Egypt Natl Canc Inst. 2005; 17(3): 139-148.

8. Faizal, A., Bujang Safawi, E., Sundram, M., Kueh, N.S., \& Normala, B. Soft tissue cover for an exposed transplanted kidney with a pedicledmyocutaneous anterolateral thigh perforator and vastus lateralis flap. UrolInt. 2011; 87(1): 117-119.

9. Saito, A., Minakawa, H., Saito, N., Isu, K., Hiraga, H., et al. Clinical experience using a tensor fascia lata flap in oncology patients. Surg Today. 2014ч 44(8): 1438-42.

10. Parada, B., Figueiredo, A., Mota, A., \& Furtado, A. Surgical complications in 1000 renal transplants. Transplant Proc. 2003; 35(3): 1085-6.

11. Sezer, T.O. \& Hoscoskun, C. Vascular complications after renal transplantation. Retrieved Nov 06, 2015, fronhhttp://cdn.intechopen.com/pdfs-wm/33577.pdf.

12. Akbar, S.A., Jafri, S.Z.H., Amendola, M.A., Madrazo, B.L., Salem, R., et al. Complications of renal transplantation. Retrieved Nov06, 2015, from: http://pubs.rsna.org/doi/pdf/10.1148/rg.255045133.

Резиме

\section{УСПЕШНА ТРАНСПЛАНТАЦИЈА НА БУБРЕГ КАЈ ПАЦИЕНТ СО МУЛТИПЛИ ПЕРИОПЕРАТИВНИ КОМПЛИКАЦИИ. ПРИКАЗ НА СЛУЧАЈ}

\section{Маргарита Пенева ${ }^{1}$, Елизабета Жоговска ${ }^{1}$, Сашо Дохчев ${ }^{2}$, Сотир Ставридис ${ }^{2}$, Александар Јосифов ${ }^{3}$, Марија Јовановски Срцева $^{4}$, Антон Дамевски ${ }^{4}$, Јосиф Јанчулев ${ }^{2}$, Јелка Масин-Спасовска ${ }^{5}$, Гоце Спасовски}

\author{
${ }^{1}$ Универзитетска клиника за пластична и \\ реконструктивна хирургија, Скопје, \\ Р. Македонија \\ ${ }^{2}$ Универзитетска клиника за урологија, Скопје, \\ Р. Македонија \\ ${ }^{3}$ Универзитетска клиника за торакална \\ хирургија, Скопје, Р. Македонија \\ ${ }^{4}$ Универзитетска клиника за анестезија, \\ реанимација и интензивно лекување, \\ Скопје, Р. Македонија \\ ${ }^{5}$ Универзитетска клиника за нефрологија, \\ Медицински факултет, Скопје, Р. Македонија
}

Бубрежните трансплантации претставуваат стандардни оперативни зафати кои имаат висок процент на успешност. Сепак, навремено откри- 
вање, поставување точна дијагноза, како и навремен третман на периоперативните хируршки компликации бараат мултидисциплинарен пристап бидејќи некои од компликациите може да резултираат со сигнификантен морбидитет, ризик од губење на графтот и/или смрт на реципиентот.

Прикажуваме случај на 24-годишен пациент кај кого се јавија низа различни хируршки компликации. Компликациите вклучуваа венска тромбоза на графтот, уринарна фистула, инфек- ција на раната, дехисценција на раната и целосно екстериоризиран трансплантиран бубрег. И покрај бројните компликации, по неколкуте ревизии, пациентот беше отпуштен од болница со уредна бубрежна функција и реставриран мекоткивен дефект.

Клучни зборови: бубрежна трансплантација, хируршки компликации, дехисценција на рана, пластична хирургија 